\title{
Export Promotion, Import Substitution and Economic Integration in Nigeria
}

\author{
Tunde G. Monogbe ${ }^{*}$, 0. John Okah ${ }^{2}$ \\ ${ }^{1}$ Department of Finance and Banking, Faculty of Management Science, University of Port Harcourt, Port Harcourt, Nigeria \\ ${ }^{2}$ Port Harcourt North Development Office, First Bank of Nigeria Limited, Port Harcourt, Nigeria \\ Email: *ol atundebusayo19@gmail.com
}

How to cite this paper: Monogbe, T.G. and Okah, O.J. (2017) Export Promotion, Import Substitution and Economic Integration in Nigeria. iBusiness, 9, 134-148. https://doi.org/10.4236/ib.2017.94010

Received: November 1, 2017

Accepted: December 19, 2017

Published: December 22, 2017

Copyright (c) 2017 by authors and Scientific Research Publishing Inc. This work is licensed under the Creative Commons Attribution International License (CC BY 4.0).

http://creativecommons.org/licenses/by/4.0/

\section{c) (i) Open Access}

\begin{abstract}
This paper empirically integrates the interplay between import substitution and export promote on the Nigerian economy in conjunction with the theoretical position of the protectionist and the free trade activist and how this has helped in promoting the Nigerian economy over the years. A disaggregate analysis of importation and exportation is conducted using a time series data between the periods 1981 to 2016. Series of econometric estimation tools were adopted in this study. Findings reveal that Non-oil export and Non-oil import seems to significantly promote economic integration in Nigeria. This report further gave in a support to trade protectionist and the trade liberalize advocates. The result of the causality test shows that before any nation could attract foreign inflows, the economy must be in good form as foreign investor only invests in an economy whose receiving capacity can sustain their investment. The study therefore concludes that before any nation could embrace liberalization, there must have been a level of threshold of industrial development in such nation.
\end{abstract}

\section{Keywords}

Economic Integration, Trade Protectionist, Trade Liberalist

\section{Introduction}

One of the ways to grow an economy even in developed markets as argued by Development economists is import substitution Cason and White [1]. According to the economic policy analysis, the developed economics promote their industrial base capacity through import substitution strategy. The process where a nation manufactures locally those commodities that were formally imported from 
overseers is known as import substitution industrialised strategy (ISIS) (Abreu, Bevilacqua \& Pinho [2]). The essence of import substitution strategy, as reported by Rotimi [3], is to ameliorate the import/export mismatch by laying emphasis on local production of commodities in the agricultural and manufacturing sector using the available local raw material to enhance economic development and thus promote balance of trade in the long run. This will however help in conserving forex and reducing over dependency on imported commodities.

The issue of forex conservancy gained predominance when the dollar to Naira exchange rate rose to an historical height in favours of dollar. Some development economists further argue that of all its benefits, import substitution benefit sometimes becomes a mirage when measures are alongside with other economics and trade policies of other countries. Notwithstanding, Development economists opine that this strategy is worthwhile for nations at the earlier stage of development. Meanwhile, some economists also argue that to hedge against scarce forex from leaving the country under the guise of importation, the local producers of this raw materials and the local manufacturers of commodities must be united so that larger percentage of this local raw materials will be consumed in their production line and this will help in forex conservation and favourable balance of trade. The argument is supported by claims that importation of these raw materials was the major causes of forex problems in Nigeria. Hence, looking inward for this raw material will spur the local production and create a market for the local commodity at home and in the international market. This will also reduce the issue of capital fighting which is a major player in exchange rate volatility and forex crisis.

According to Ezeh [4], some of the benefits of import substitution include forex conservancy, reduced import dependency, and local productivity and industrial enhancement. Looking inward for materials in the process of production will accelerate local industrial growth and also create a market for local materials in the international competition which will transmit into increased government revenue through the window of Taxation.

A convenient and instructive way to approach the complex issue of appropriate trade policies for development is to set this polices in the context of a strategic inward or outward looking Todaro and Smith [5]. The trade integration of any nation is lingered on the interplay between her import substitution and export promotion given the present situation of the nation at that point in time. According to Paul Streeten, the outward looking development policies gives rooms for trade liberalization which further facilitate movement of capital, resources, technology and the multinational intervention in the economic activities of the LDC. Conversely, the inward looking development policies stressed the need for developing countries like Nigeria to evolve their own style of development and to control their own destiny. This therefore suggests that policies to encourage indigenous trade through manufacturing and agriculture should be embrace and development of indigenous technology springing from the country's resources 
endowment should be celebrated. According to the trade protectionist who beliefs in inward looking development polices, developing countries can only gain self-reliance and inward growth if an only if trade is restricted and the multinational enterprises with their wrong technology, using the developing countries as their dumping ground seized.

This opinion of putting an end to the operation of the multinational firm in the LCD as attracts a lot of debate in the literature. In support to the view of the trade protectionist, Griffin and Enos [5], assert that there exists a parasitic relationship between foreign capital inflows and economic development as their complicate the problems of the LDC's through the importation of outdated technology and negatively deepening level of underdevelopment in the LDC's to enrich their own pulse. FDI intelligent analysis [6] reported that Nigeria consumes over $15 \%$ of the total capital inflow into the African continent which corroborate the report of the UNCTAD World business analysis [7] yet, the effect of these enormous inflows is yet to be felt to a reasonable extent Monogbe and Nduka [8].

In this two philosophical approach to development of a nation, the free trade activist advocates outward looking export promotion strategy to economic integration while the protectionist approves inward looking import substitution strategy. Breaking it down to the Nigeria context, Nigerian economy has being a major player in the international crude market as the larger percentage of her exportation is crude oil. Before the discovery of crude, Nigerian government paddle her economy through the exportation of agricultural product. The discovery of oil led to a paradigm shift from the agricultural and mining sector to crude oil which account for a larger percentage of her GDP today. The recent economic maladaptation and imbalances has resuscitated the long forgotten and ignored agricultural sector. This diversification process has resuscitated all other sector as the nation needs to finance her budget on the yearly basis.

Accordingly, the report from the CBN statistical Bulletin 2016 issues, the ratio of exportation to importation is 60:40 though the larger quantum of export falls under crude exportation since 1981 to 1997, while in 1998, import takes the lead as it value stood at 837.4 billion naira while exportation drops for the first time in the trend from 1241.7 billion to 751.9 billion. From 1999 to 2014, exportation has being taking the lead while import follows but in 2015, total exportation drops from 12,007.0 oil export and non-oil export 953.5 to 8184.5 oil export and 660.7 non-oil export. This drastic drop in the oil exportation could be anchored on the inelasticity of demand of crude in the world market during the early quarter of 2015. On the whole, the Nigerian economy has being export leading and import following which is a condition for favourable balance of trade. But, instead of enjoying favourable balance of trade, reverse is the case.

This study therefore tend to integrate the coalition of import and exportation on the Nigeria economy in conjunction with the theoretical position of the protectionist and the free trade activist and how this has help in promoting the $\mathrm{Ni}$ - 
gerian economy over the years. A disaggregate analysis of import and exportation will be conducted using a time series data between the period 1981 to 2016 .

\section{Theoretical Underpinning}

\subsection{Todaro and Smith (2003) Postulation on Export Expansion}

The promotion of LDC primary or secondary exports has long been considered as a major prerequisite in achieving a viable long run development grant Todaro and Smith [9]. A classic example of primary outward-looking regions was the colonial territories of African and Asian, with their foreign owned mines and plantations. It was partly in reaction of this enclave economic structure and partly as a consequences of the industrialization bias of the 1950s and the 60s that the newly independent state and the old existing state of the African and Asian put massive emphasis on the production of manufactured goods initially for the home market (secondary inward) and then for export (secondary outward).

Similarly, most low-income less development countries still rely on primary product for most of their export earnings. Moreover, the LDC share of these exports has been falling over the past few decades. This is because food, Non-food agricultural product and raw materials makes up almost $40 \%$ of her total export and for many poor countries, it constitutes their principal source of foreign exchange earnings. The question then arose that why the total export of the LDC dropping is since exportation is a key for favourable term of trade? Hence, the factors that affect the demand and supply of primary product export are stated thus. On the demand side, there appear to be at least five factors working against the rapid expansion of the LDC primary product and especially agricultural exports to the developed nation. Firstly, the income elasticity of demand for agricultural food stuff and raw materials are relatively low compared with those of fuels, certain minerals and manufacturers. Secondly, developed countries population growth rates are now at or near the replacement level, so little expansion can be expected from these resources. Thirdly, the price elasticity of demand form most primary commodities is relatively low. When relative agricultural price are falling, as they have been during most of the past three decades, such low elasticity mean less total revenue for exporting nation. The fourth and fifth factors working against the long run expansion of LDC primary-product export earnings-the development of Synthetic substitutes and the growth of agricultural production in the developed countries-are perhaps the most important. And on the supply side, a number of factors also work against the rapid expansion of primary product earnings. The most important is the structural rigidity of many rural production systems in developing countries. We may conclude, therefore that the successful promotion of primary-product export cannot occur unless there is a reorganization of rural social and economic structure.

\subsection{Review of Related Literature}

Aregbeshola [10] using generalized movement of analysis (GMM) test the posi- 
tion of trade activist on the BRICS economy. The protectionist advocated that local production should be developed and massive exportation of the local commodity should be embrace while the free trade activist opines that tolerating the multinational firm and importation will help in developing the less developed countries and also enhance inflows of capital and materials for development purposes. The study tend to test which of this strategy has helped this BRICS nations, the study employed a panel regression analysis and a Generalised movement of analysis. The study first identified that before any nation could embrace liberalization, there must have been a level of threshold of industrial development in such nation. Secondly, the study conclude that developing countries should follow the opinion of the protectionist by encouraging local production and exportation of local product in the long run while in the short run, liberalization should be encouraged as a percentage of this is needed for economic development before the nation could pick from their stage of development.

Monogbe and Nduka [8] empirically test run the contribution of the liberalized economic system through the inflow of foreign investment against the operation of the internal financial institution. The intension of the study was to identify whether liberalization promote economic development or the internal financial administration of the nation is capable of enhancing economic development in Nigeria. Time series data from the statistical bulletin was considered where foreign direct investment and trade openness was proxies for liberalization and aggregate bank loans and interest rate was used as a proxy for financial development in Nigeria. Study reveals the existence of long run association among employed variables after the time series employed became stationary after first differencing in the order of 1(1) integration. The report of the causality test established that liberalization could serve as a catalyst for economic development in the long run while the operation of the internal financial institution is parasitic to economic advancement. Hence the study recommend that Economic, political and institutional environment should be well stabilised to encourage more inflows of foreign capital.

Ozurumba and Chigbu [11] econometrically examined the connection between export and industrialization development in Nigeria between the periods 1986 to 2015 using auto regressive distributive lag mechanism. The study was extended to the area of liberalization as variables like trade openness, average tariff, exchange rate, and manufacturing export were considered. Findings reveals that all variables under investigation respond in a significant manner to net export except for openness and manufacturing capacity utilization which appear to be insignificant in stimulating manufacturing export. Within the context of the study, it was proof that countries practicing export promotion pattern of trade stands that chance of becoming more competitive and productive compare to countries strictly focusing on import substitution strategy. The study thereby recommend that Trade policies in the country must be re-appraised, reviewed and reinvigorated so as to maximize the gain from foreign trade. This could help boost our level of productivity and make the economy more competitive. 
Monogbe [12] examine the behavioural effect of the multinational operation and its performance on the Nigeria economy between the periods 1986 to 2014 . Study employs granger causality test, multiple regression and unit root test to ascertain the level of stationarity. Findings reveals that the operation of the foreigner inform of FDI has significantly stimulate economic growth in the long run in Nigeria. Hence, study recommends that the political and economic environment should be normalised to encourage more foreign capital inflows.

Eneje and Ikpo [13] using multiple regression of the ordinary least square empirically examined 17 African countries focusing on the major determinant of diversification in Africa since it is seen as a catalyst to promote economic development in the long. Par capital income, human capital, investment, geographical location and good governments were considered as crux indicators of diversification. Finding reveals that all variables under investigate are significant drivers of export diversification while term of trade and population react in an inverse manner to export diversification.

Monogbe and Achugbu [14] examine the dynamic effect of foreign capital inflow on the development of the Nigerian economy using time series data between the periods 1891 to 2014. Study employs error correction model, Cointegration test and granger causality test among others. Finding reveals that foreign capital inflow has statistically and significantly promote economic development in the Nigerian context although the practical effect of its contribution is not been felt to a great extent. Study then conclude that financial discipline and moral tolerance such be embraced in order to achieve the motive of foreign inflows and hence promote economic development in Nigeria in the long run.

Sheng [15] Examined the phases of development in the china economy in the face of development strategy and trade reform. The study structured the stages of trade development in china into four different phases. The first phase kick starts from the WTO agreement between the periods 1980 to 1983 which was tagged import substitution and marginal export promotion. The second phase kick starts around 1984 to 1990 which an export promotion kicking out import substitution. The third stage is a combination of export promotion and liberalization strategy which gives room for the china economy to enjoy inflow of technology and massive production of commodity which was later exported to developing counties. The last phases of development took place in 1994 to 2001 which massively embrace radical liberalization which open doors for international inflow and outflows of resources and materials. At present, the trade strategy driving the Chinese economy targeted toward addressing and recovering from the global financial crises. The trade strategy adopted by the Chinese economy has helped in bailing her out and experiencing gradual recovery which has further promote external demand in 2010 till date.

Greenway and Num as cited in Kankesu [16] opines that mono trade criterion approach is inefficient is driving an economy to a development gland. Their study reported that this is made impossible via four reasons which include all countries operative and leverage on her comparative cost advantage to envelope develop- 
ment, trade policies differs per countries. Hence specializing on single trading approach might not help in achieving the development planned of the state. Kankesu [16] in his study of import substitution verse export promotion concluded that single criterion strategy of import substitution is likely to reduce potential export and limited domestic market where industry unlikely to reap the benefits of economies-of-scale.

Musibau [17] empirically investigate the influence of trade policy integration on export performance of selected ECOWAS state between the period 1980 and 2004 using gravity model. The study reveals that if all ECOWAS member will comply with the trade agreement and adopt reduced trade barrier strategy, export performance in the African region will be stimulated and consistent.

\section{Methodological Framework}

This study employed descriptive research design and the choice of this research design is anchored on the fact that the study covers an empirical structure and an analytical structure. Time series data were sourced from the central bank of Nigeria statistical bulletin between the periods 1981 to 2016 where oil export, non-oil export, oil import, non-oil import and foreign direct investment were proxies for export promotion and import substitution while economic integration index is used as proxy for economic integration. The objective of this paper is to integrate the coalition of importation and exportation on the Nigeria economy in conjunction with the theoretical position of the protectionist and the free trade activist and how this has help in promoting the Nigerian economy over the years

\subsection{Model Specification}

The classical linear regression model assumption will be adopted in this study. For simplicity purposes, we formulated our model in a functional form thus

$$
\begin{gathered}
E I I=f(\text { OEXP, NOEXP, OIMP, NOIMP, FDI }) \\
E I I_{t}=\beta_{0}+\beta_{1} O E X P_{t}+\beta_{2} N O E X P_{t}+\beta_{3} \text { OIMP }_{t}+\beta_{4} N O I M P_{t}+\beta_{5} F D I_{t}+\lambda_{t}
\end{gathered}
$$

where;

$$
\begin{aligned}
& O E X P=\text { Oil Export; } \\
& N O E X P=\text { Non-oil Export; } \\
& O I M P=\text { Oil import; } \\
& N O I M P=\text { Non-oil import; } \\
& F D I=\text { Foreign direct investment; } \\
& \beta_{1}-\beta_{5}=\text { Slope; } \\
& \lambda_{t}=\text { Error Term. }
\end{aligned}
$$

\subsection{A Priori Expectation}

Based on theoretical underpinning and empirical studies, we expect that the predictor variable have a positive nexus with the dependent variable and it is ma- 
thematically stated thus:

$$
\beta_{1}, \beta_{2}, \beta_{3}, \beta_{5} \text { and } \beta_{5}>0
$$

\section{Presentation of Data and Result}

Time series data are prone to stationarity problems (Gujarati and Porter, 2009) (Table 1), hence data are expected to be subjected to time stationarity test to determine their reliability strength. Following this postulation (Table 1), we subject our time series to stationarity test thus.

Thus far, report shows that all-time series has unit root at level which nullifies the stationarity strength of the data (Table 2), test at the second level shows that all-time series under investigation become stationary in the order of 1(1) integration. This therefore suggests that the data is set for further econometric investigation.

The essence of co-integration test is to ascertain the co-existence of long run association among the employed variables under investigation (Table 3). The report above shows that existence of four co-integrating equations which implies that the data set is jointly related in the long run. Hence error correction model is appropriate.

The essence of error correction is to ascertain the speed at which the error in the short run is corrected in the long run (Table 4). The ECM coefficient stood at -0.00041 alongside a corresponding significant $\mathrm{P}$-value of 0.0296 . This suggests that in the short run distortion in the short run can be corrected to the tune of 0.0004 unit. Two of the five explanatory variables under investigation appear to be significant in promoting financial integration in Nigeria. Non-oil export exhibit a significant $\mathrm{P}$-value of 0.0032 alongside a positive coefficient of 0.307674 . This shows that Non-oil export which covers all form of production and services seems to stimulate economic integration in Nigeria. The report here harmonizes with the opinion of the protectionist and the free trade advocate. The economic implication of this is that injection of fund into the various domestic sectors of the economy could result into a massive output of local commodities and enhance a massive exportation. Further, Non-oil importation also exhibits a significant $\mathrm{P}$-value of 0.0009 with a corresponding positive coefficient of 0.66177 . This goes a long way to explain the importance of inflows into the nation. The report here negate the opinion of the protectionist and Enos [18], whose investigation shows that there exists a parasitic relationship between foreign capital inflows and economic development as their complicate the problems of the LDC's through the importation of outdated technology and negatively deepening level of underdevelopment in the LDC's to enrich their own pulse. Oil import and foreign direct investment possess a negative relationship to economic integration.

From the global statistics, the adjusted $\mathrm{R}^{2}$ stood at 0.984922 while the Durbin Watson statistic exhibit a coefficient of 1.5199 which is in line with the acceptable range thus suggesting absence of auto correlation problems. On the whole, 
Table 1. Economic integration (EII), oil export (OEXP), non-oil export (NOEXP), oil import (OIMP), non-oil import (NOIMP) and foreign direct investment (FDI).

\begin{tabular}{|c|c|c|c|c|c|c|}
\hline Years & EII & OEXP & NOEXP & OIMP & NOIMP & FDI \\
\hline 1981 & 12.49 & 10.70 & 0.30 & 0.10 & 12.70 & 334.70 \\
\hline 1982 & 12.80 & 8.00 & 0.20 & 0.20 & 10.50 & 290.00 \\
\hline 1983 & 16.07 & 7.20 & 0.30 & 0.20 & 8.70 & 264.30 \\
\hline 1984 & 16.63 & 8.80 & 0.20 & 0.30 & 6.90 & 360.40 \\
\hline 1985 & 17.77 & 11.20 & 0.50 & 0.10 & 7.00 & 434.10 \\
\hline 1986 & 18.36 & 8.40 & 0.60 & 0.90 & 5.10 & 735.80 \\
\hline 1987 & 28.66 & 28.20 & 2.20 & 3.20 & 14.70 & 2452.80 \\
\hline 1988 & 40.14 & 28.40 & 2.80 & 3.80 & 17.60 & 1718.20 \\
\hline 1989 & 62.61 & 55.00 & 3.00 & 4.70 & 26.20 & $13,877.40$ \\
\hline 1990 & 69.33 & 106.60 & 3.30 & 6.10 & 39.60 & 4686.00 \\
\hline 1991 & 80.84 & 116.90 & 4.70 & 7.80 & 81.70 & 6916.10 \\
\hline 1992 & 120.51 & 201.40 & 4.20 & 19.60 & 123.60 & $14,463.10$ \\
\hline 1993 & 195.09 & 213.80 & 5.00 & 41.10 & 124.50 & $29,675.20$ \\
\hline 1994 & 306.41 & 200.70 & 5.30 & 42.30 & 120.40 & $22,229.20$ \\
\hline 1995 & 529.87 & 927.60 & 23.10 & 155.80 & 599.30 & $75,940.60$ \\
\hline 1996 & 690.70 & 1286.20 & 23.30 & 162.20 & 400.40 & 111295.00 \\
\hline 1997 & 758.97 & 1212.50 & 29.20 & 166.90 & 678.80 & 110452.70 \\
\hline 1998 & 859.83 & 717.80 & 34.10 & 175.90 & 661.60 & $80,750.40$ \\
\hline 1999 & 939.50 & 1169.50 & 19.50 & 211.70 & 650.90 & $92,792.50$ \\
\hline 2000 & 1020.39 & 1920.90 & 24.80 & 220.80 & 764.20 & $115,952.20$ \\
\hline 2001 & 1243.26 & 1839.90 & 28.00 & 237.10 & 1121.10 & $132,481.00$ \\
\hline 2002 & 1494.24 & 1649.40 & 94.70 & 361.70 & 1151.00 & $225,224.80$ \\
\hline 2003 & 1783.85 & 2993.10 & 94.80 & 398.90 & 1681.30 & $258,388.60$ \\
\hline 2004 & 2871.53 & 4489.50 & 113.30 & 318.10 & 1668.90 & $248,224.60$ \\
\hline 2005 & 3614.03 & 7140.60 & 106.00 & 797.30 & 2003.60 & 1921.21 \\
\hline 2006 & 5303.85 & 7191.10 & 133.60 & 710.70 & 2397.80 & 4111.49 \\
\hline 2007 & 5889.95 & 8110.50 & 199.30 & 768.20 & 3143.70 & $109,161.30$ \\
\hline 2008 & 6776.71 & 9861.80 & 525.90 & 1315.50 & 4277.60 & $124,645.00$ \\
\hline 2009 & 7897.09 & 8105.50 & 500.90 & 1068.70 & 4411.90 & $227,093.30$ \\
\hline 2010 & 8992.65 & $11,300.50$ & 711.00 & 1757.10 & 6406.80 & $137,029.20$ \\
\hline 2011 & $10,325.57$ & $14,323.20$ & 913.50 & 3043.60 & 7952.30 & $125,668.71$ \\
\hline 2012 & $11,843.53$ & $14,260.00$ & 879.30 & 3064.30 & 6702.30 & $844,363.70$ \\
\hline 2013 & $13,702.84$ & $14,131.80$ & 1130.20 & 2429.40 & 7010.00 & $369,020.53$ \\
\hline 2014 & $15,704.13$ & $12,007.00$ & 953.50 & 2215.00 & 8323.70 & $1,255,273.80$ \\
\hline 2015 & $18,028.90$ & 8184.50 & 660.70 & 1725.20 & 9350.80 & $1,233,796.10$ \\
\hline 2016 & $20,675.86$ & 8178.80 & 656.80 & 2384.40 & 7096.00 & $1,439,251.20$ \\
\hline
\end{tabular}

Sources: Extraction from CBN Statistical Bulletin. 
Table 2. Reliability test.

\begin{tabular}{ccccc}
\hline Variables & ADF Stat & $5 \%$ critical value & Order & Remark \\
\hline D(LOG(EI) & -3.739504 & -2.95112 & $1(1)$ & Stationary \\
D(LOG(FDI) & -7.8804 & -2.9571 & $1(1)$ & stationary \\
D(LOG(NOEXP) & -6.8884 & -2.9511 & $1(1)$ & Stationary \\
D(LOG(NOIMP) & -7.0887 & -2.9511 & $1(1)$ & stationary \\
D(LOG(OEXP) & -4.2987 & -2.9511 & $1(1)$ & stationary \\
D(LOG(OIMP) & -6.5786 & -2.61430 & $1(1)$ & stationary \\
\hline
\end{tabular}

Source: Extraction from E-views.

Table 3. Presentation of co-integration.

Date: 10/24/17 Time: 09:00

Sample (adjusted): 19832016

Included observations: 34 after adjustments

Trend assumption: Linear deterministic trend

Series: EII FDI NOEXP NOIMP OEXP OIMP

Lags interval (in first differences): 1 to 1

Unrestricted Cointegration Rank Test (Trace)

\begin{tabular}{ccccc}
\hline Hypothesized & & Trace & 0.05 & \\
\hline No. of CE(s) & Eigenvalue & Statistic & Critical Value & Prob. $^{* *}$ \\
\hline None & 0.978137 & 378.4485 & 95.75366 & 0.0001 \\
At most $1^{*}$ & 0.942356 & 248.4672 & 69.81889 & 0.0000 \\
At most $2^{*}$ & 0.903258 & 151.4493 & 47.85613 & 0.0000 \\
At most $3^{*}$ & 0.685625 & 72.03544 & 29.79707 & 0.0000 \\
At most $4^{*}$ & 0.474501 & 32.69167 & 15.49471 & 0.0001 \\
At most 5 & 0.172479 & 20.81582 & 3.841466 & 0.0610 \\
\hline
\end{tabular}

Trace test indicates 6 cointegrating eqn(s) at the 0.05 level; ${ }^{*}$ : Denotes rejection of the hypothesis at the 0.05 level; ${ }^{* *}$ : MacKinnon-Haug-Michelis (1999) p-values. Source: Extraction from E-views.

the F-statistics with its corresponding P-value approves the significances of non-oil export and non-oil import as a major stimuli to economic integration. This thus shows that neither the single trade policy (protectionist) nor the free trade policy (liberalized economy) is sufficient in enhancing economic development of a nation but, duo policy will produce a better result.

\section{Residual Diagnostic Test}

In establishing the validity and reliability of the model, heteroskedasticity test is conducted (Table 5). The decision rule suggest that if the observed $\mathrm{R}^{2}$ is greater than the preferred level of significant (5\%) is null hypothesis of presence of heteroskedasticity problems will be ignored and if otherwise, we do not reject. The 
Table 4. Error correction model.

Dependent variable: LOG(EII)

Method: least squares

Date: 10/24/17 Time: 11:36

Sample (adjusted): 19822016

Included observations: 35 after adjustments

\begin{tabular}{cclcc}
\hline Variable & Coefficient & \multicolumn{1}{l}{ Std. Error } & t-Statistic & \multicolumn{1}{c}{ Prob. } \\
\hline C & 1.816521 & 0.595250 & 3.051697 & 0.0049 \\
LOG(FDI) & -0.033770 & 0.046743 & -0.722471 & 0.4760 \\
LOG(NOEXP) & 0.307674 & 0.095442 & 3.223667 & 0.0032 \\
LOG(NOIMP) & 0.661772 & 0.178255 & 3.712502 & 0.0009 \\
LOG(OEXP) & 0.011378 & 0.187074 & 0.060822 & 0.9519 \\
LOG(OIMP) & -0.001118 & 0.106720 & -0.010478 & 0.9917 \\
ECM(-1) & $-5.41 \mathrm{E}-06$ & $6.07 \mathrm{E}-05$ & -0.089175 & 0.0296 \\
R-squared & 0.987583 & Mean dependent var & 6.550935 \\
Adjusted R-squared & 0.984922 & S.D. dependent var & 2.421765 \\
S.E. of regression & 0.297377 & Akaike info criterion & 0.589223 \\
Sum squared resid & 2.476123 & \multicolumn{2}{c}{ Schwarz criterion } & 0.900293 \\
Log likelihood & -3.311404 & Hannan-Quinn criter. & 0.696604 \\
F-statistic & 371.1514 & Durbin-Watson stat & 1.519956 \\
Prob (F-statistic) & 0.000000 & r & \\
\hline
\end{tabular}

Source: Extraction from E-views.

Table 5. Heteroskedasticity test.

\begin{tabular}{cccc}
\hline \multicolumn{4}{c}{ Heteroskedasticity Test: Breusch-Pagan-Godfrey } \\
\hline F-statistic & 0.787041 & Prob. F $(6,28)$ & 0.5875 \\
Obs ${ }^{*}$ R-squared & 5.050957 & Prob. Chi-Square (6) & 0.5373 \\
Scaled explained SS & 2.903068 & Prob. Chi-Square (6) & 0.8209
\end{tabular}

Source: Extraction from E-views.

report shows that the observed $\mathrm{R}^{2}$ exhibit a coefficient higher than the level of significant (0.5373). This therefore suggests that we ignore the null hypothesis and thus concludes that the model is free from heteroskedasticity problem which is a good sign of fineness of the model (Figure 1).

The essence of the normality test is to identify the distribution of the residual to ensure normalcy and to establish the viability of the model. The decision here states that if the P-value is greater than the preferred level of significant (0.005) we reject the null hypothesis and thus conclude that the residual is normally distributed. From the report above, the P-value exhibit a coefficient of 0.8736 which 


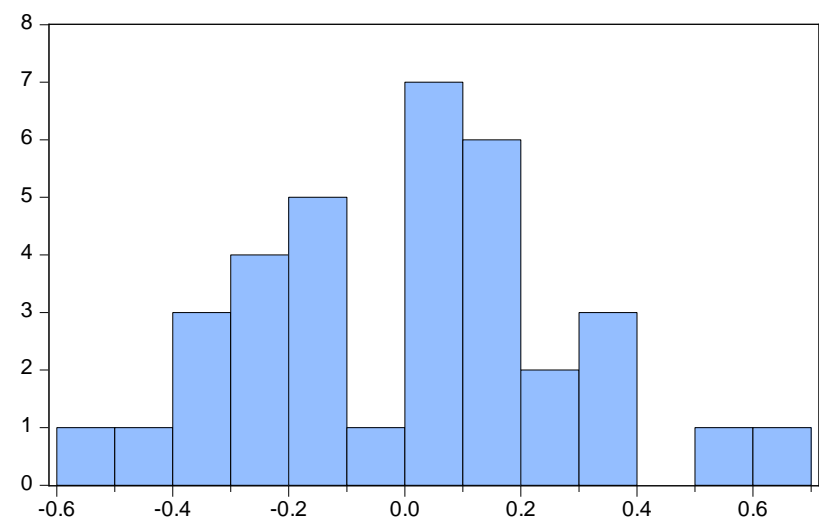

\begin{tabular}{|lr|}
\hline \multicolumn{2}{|l|}{ Series: Residuals } \\
Sample 1982 2016 \\
Observations 35 \\
Mean & $-1.28 \mathrm{e}-15$ \\
Median & 0.014106 \\
Maximum & 0.639216 \\
Minimum & -0.566179 \\
Std. Dev. & 0.269865 \\
Skewness & 0.189574 \\
Kurtosis & 2.796113 \\
& \\
Jarque-Bera & 0.270263 \\
Probability & 0.873601 \\
\hline
\end{tabular}

Figure 1. Jarque-Bera normality. Source: Extraction from E-views.

Table 6. Serial correlation.

\begin{tabular}{cccc}
\hline \multicolumn{4}{c}{ Breusch-Godfrey Serial Correlation LM Test: } \\
\hline F-statistic & 0.801660 & Prob. F(2,26) & 0.4594 \\
Obs ${ }^{*}$ R-squared & 2.032952 & Prob. Chi-Square(2) & 0.3619 \\
\hline
\end{tabular}

Source: Extraction from E-views.

Table 7. Granger causality test.

Pairwise Granger Causality Tests

Date: 10/25/17 Time: 08:06

Sample: 19812016

Lags: 1

\begin{tabular}{cccc}
\hline Null Hypothesis: & Obs & F-Statistic & Prob. \\
\hline LOG(FDI) does not Granger Cause LOG(EII) & 35 & 0.45671 & 0.5040 \\
LOG(EII) does not Granger Cause LOG(FDI) & & 5.19486 & 0.0295 \\
LOG(NOEXP) does not Granger Cause LOG(EII) & 35 & 0.64037 & 0.4295 \\
LOG(EII) does not Granger Cause LOG(NOEXP) & & 4.51453 & 0.0414 \\
LOG(NOIMP) does not Granger Cause LOG(EII) & 35 & 0.02975 & 0.8641 \\
LOG(EII) does not Granger Cause LOG(NOIMP) & & 8.76847 & 0.0057 \\
LOG(OEXP) does not Granger Cause LOG(EII) & 35 & 1.28724 & 0.2650 \\
LOG(EII) does not Granger Cause LOG(OEXP) & & 1.00136 & 0.3245 \\
LOG(OIMP) does not Granger Cause LOG(EII) & 35 & 14.7797 & 0.0005 \\
LOG(EII) does not Granger Cause LOG(OIMP) & & 0.95895 & 0.3348 \\
\hline
\end{tabular}

Source: Extraction from E-views.

is greater than $5 \%$ level of significant. Hence, we reject the null hypothesis and conclude that the residual are normally distributed.

The report above (Table 6) validate the classical linear regression model assumption as its Observed $\mathrm{R}^{2}$ exhibit a P-value higher than $0.05 \%$ level of significant. This implies that our model is fit for forecasting and free from serial corre- 
lation problems as expected.

The result (Table 7) of the causality give a clear interplay between import substitution and export promotion indices and how there promote economic integration in Nigeria. From the result presented, we found a unidirectional relationship between foreign direct investment and economic integration indices with causality flowing from EII to FDI. The economic implication of this is that foreign invest consider a fatal economy before considering the choice of investing in such nation. Meaning that for there to be more inflows of foreign investment, the host country must have some sweeteners to attract foreign investors. The result I in support of the trade protectionist who beliefs in developing the local technology to accelerate massive local productivity and promote exportation. Further, Non-oil export seems to stimulate economic integration as causality flows from the economy to non-oil export. This implies that for there to be a massive productivity and exportation, the government must play a lead role by encouraging local producer through issuance of loan and other benefit scheme. Also, finally, the study recognised the significant of oil import as this constitute the major source of revenue to the nation. The study further shows that oil import seems to promote economic integration as causality flows from OIMP to EII. In summary, the collective effort of both trade policies (import substitution and export promotion) is capable of promote active economic growth in Nigeria if properly managed.

\section{Concluding Remarks}

This study was succeeded in integrating the coalition of importation and exportation of commodities on the Nigeria economy in conjunction with the theoretical position of the protectionist and the free trade activist and how this has helped in promoting the Nigerian economy over the years. A disaggregate analysis of importation and exportation is conducted using a time series data between the period 1981 to 2016.

On the whole, series of econometric estimation tools were adopted in this study. In the error correction model result, Non-oil export and Non-oil import seems to significantly promote economic integration in Nigeria. This report further gave in a support to trade protectionist and the trade liberalize advocates. The result of the causality test shows that before any nation could attract foreign inflows, the economy must be in good form as foreign investor only invests in an economy whose receiving capacity can sustain their investment. We found a unidirectional causal relationship between foreign direct investment and economic integration in Nigeria with causality flowing from economic integration to foreign direct investment in Nigeria. Further, oil import is proved to be significant in stimulating economy advancement in Nigeria as it causal relationship flows from OIMP to EII. The interplay between oil import and the Nigerian economy is not a strange one as the major source of the Nigeria government revenue is generated from exportation and importation of crude. 
In the light of this study, the following identifications were noted:

- Before any nation could embrace liberalization, there must have been a level of threshold of industrial development in such nation.

- Secondly, the study concludes that developing countries should follow the opinion of the protectionist by encouraging local production and exportation of local product in the long run while in the short run, liberalization should be encouraged as a percentage of foreign inflows are needed for economic development before the nation could pick from their stage of development.

- Finally, the study concludes that both trade policies (import substitution and export promotion) are essential in accelerating economic advancement in any nation.

Hence, this study recommends that to enhance economic development of the developing countries, Trade remedy measured should be launched as this measure has help the Chinese's economy in the time of economic meltdown.

\section{References}

[1] Greenaway, D. and Nam, C.H. (1988) Industrialisation and Macroeconomic Performance in Developing Countries under Alternative Trade Strategies. Kyklos, 41, 419-435. https://doi.org/10.1111/j.1467-6435.1988.tb01263.x

[2] Abreu, M.P., Bevilacqua, S.A. and Pinho, M.D. (1996) Import Substitution and Growth in Brazil, 1890-1970. Texto para Discussion 366, PUC-RJ.

[3] Rotimi, O. (2017) Import Substitution and Export Promotion. This Day's Newspaper.

[4] Ezeh, W. (2017) Import Substitution and Export Promotion. This Day's Newspaper.

[5] Griffin, T. and Enos, O. (1970) Foreign Direct Investment as a Catalyst to Less Developing Countries Growth. International Journal of Finance, 6, 123-132.

[6] FDI Intelligent Analysis (2015) Foreign Direct Investment Analysis on Developing Countries. International Summit to Economic Development, Ghana, 10 October 2015.

[7] UNCTAD (2009) UNCTAD World Business Analysis. UNCTAD, Geneva.

[8] Monogbe, T.G. and Nduka, J.A. (2016) Driving Nigerian Economic Development: Foreign Inflow or Financial Development? Proceeding of Faculty of Management Science 2016 International Conference, 8-10 November 2016, 486-501.

[9] Todaro, M.P. and Smith, S.C. (2006) Economic Development. 8th Edition, Addison-Wesley, Reading.

[10] Aregbeshola, R.A. (2017) Import Substitution Industrialization and Economic Growth: Evidence from the Group of BRICS Countries. Future Business Journal, 3, 138-158. www.sciencedirect.com

[11] Ozurumba, B.A. and Chigbu, E.E. (2016) Export Oriented Industrialization: An Econometric Investigation of Nigeria. Proceeding of Faculty of Management Science 2016 International Conference, 8-10 November 2016.

[12] Monogbe, T.G. (2016) The Behavioural Effect of Multinational Operations and Its Performance on the Nigeria Economy (An Empirical Investigation). International Journal of Economics, Finance and Management Sciences, 4, 143-152. https://doi.org/10.11648/j.ijefm.20160403.17

[13] Eneje, B.C. and Ikpo, I.M. (2016) Export Diversification Determinant in Africa. Proceeding of Faculty of Management Science 2016 International Conference, 8-10 
November 2016, 386-394

[14] Monogbe, T.G. and Achugbu, A. (2016) Capital Inflow and Its Dynamic Effect on Economic Development in Nigeria. Account and Financial Management Journal, 1, 227-239.

[15] Sheng, G. (2015) China's Trade Development Strategy and Trade Policy Reform: Overview and Prospect. Ph.d Dissertation, Nankai University, Tianjin.

[16] Kankesu, J. (2000) Industrialisation: Import Substitution to Export Promotion. Economics Working Papers. University of Wollongong, Wollongong.

[17] Musibau, A.B. (2006) Trade Policy Reform, Regional Integration and Report Performance in the ECOWAS Sub-Region. Online Publications.

[18] Enos, O. (1970) The State as Naïve Entrepreneur: The Political Economic of Exportation Promotion in Brazil and Yunisia. Policy Study Journal, 26, 46-68. 